\title{
OPEN Modelling of hydrogen sulfide fate and emissions in extended aeration sewage treatment plant using TOXCHEM simulations
}

\author{
Haider M. Zwain ${ }^{1,2 \bowtie}$, Basim K. Nile ${ }^{3}$, Ahmed M. Faris ${ }^{4,5}$, Mohammadtaghi Vakili6 \& \\ Irvan Dahlan 7,8
}

Odors due to the emission of hydrogen sulfide $\left(\mathrm{H}_{2} \mathrm{~S}\right)$ have been a concern in the sewage treatment plants over the last decades. $\mathrm{H}_{2} \mathrm{~S}$ fate and emissions from extended aeration activated sludge (EAAS) system in Muharram Aisha-sewage treatment plant (MA-STP) were studied using TOXCHEM model. Sensitivity analysis at different aeration flowrate, $\mathrm{H}_{2} \mathrm{~S}$ loading rate, wastewater $\mathrm{pH}$, wastewater temperature and wind speed were studied. The predicted data were validated against actual results, where all the data were validated within the limits, and the statistical evaluation of normalized mean square error (NMSE), geometric variance (VG), and correlation coefficient (R) were close to the ideal fit. The results showed that the major processes occurring in the system were degradation and emission. During summer $\left(27^{\circ} \mathrm{C}\right)$ and winter $\left(12{ }^{\circ} \mathrm{C}\right)$, about 25 and $23 \%, 1$ and $2 \%, 2$ and $2 \%$, and 72 and $73 \%$ were fated as emitted to air, discharged with effluent, sorbed to sludge, and biodegraded, respectively. At summer and winter, the total emitted concentrations of $\mathrm{H}_{2} \mathrm{~S}$ were 6.403 and $5.614 \mathrm{ppm}$, respectively. The sensitivity results indicated that aeration flowrate, $\mathrm{H}_{2} \mathrm{~S}$ loading rate and wastewater $\mathrm{pH}$ highly influenced the emission and degradation of $\mathrm{H}_{2} \mathrm{~S}$ processes compared to wastewater temperature and wind speed. To conclude, TOXCHEM model successfully predicted the $\mathrm{H}_{2} \mathrm{~S}$ fate and emissions in EAAS system.

Odors emission from sewage treatment plants (STPs) are longstanding environmental issue that receives ongoing attention as a result of urbanization and population expansion. The emission of odors from STPs causes unpleasant nuisances for plant workers and people nearby. Odors cause several health effects such as headache, nausea, and respiratory-related issues. Some odors can be toxic and cause adverse health impacts such as death. Furthermore, odor has negative social economic effects by reducing the price of properties and prospects for tourism due to esthetic nuisance ${ }^{1}$.

Apart from that, odor problems close to STPs were associated with hydrogen sulfide $\left(\mathrm{H}_{2} \mathrm{~S}\right)$ emission as a major source for annoying odors even at very low concentrations. $\mathrm{H}_{2} \mathrm{~S}$ is colorless, flammable, associated with a rotten egg smell and very toxic gas. $\mathrm{H}_{2} \mathrm{~S}$ is generated from the combination of decomposition of organic sulfur from feces and reduction of inorganic sulfur compounds from the sulfate ion $\left(\mathrm{SO}_{4}{ }^{2-}\right)$ by bacteria and archaea under anaerobic conditions ${ }^{2}$. $\mathrm{H}_{2} \mathrm{~S}$ has very low odor threshold limit, however its malodor can even be noticed below $1 \mathrm{ppm}$, whereas human's odor threshold between 0.0005 and $1.5 \mathrm{ppm}$. Long human's exposure $(8 \mathrm{~h})$ to concentrations ranges from 2 to $5 \mathrm{ppm}$ causes headache, nausea and tearing of eyes, while concentration of $50 \mathrm{ppm}$ causes respiratory tract irritation. Single exposure to $500 \mathrm{ppm}$ results in sudden unconsciousness and death if the levels are over $1000 \mathrm{ppm}^{3}$.

${ }^{1}$ College of Water Resources Engineering, Al-Qasim Green University, Al-Oasim, Babylon 51013, Iraq. ${ }^{2}$ Department of Civil and Architectural Engineering, College of Engineering, Sultan Qaboos University, Al Khoudh, P.O. Box 33, 123 Muscat, Oman. ${ }^{3}$ College of Engineering, University of Kerbala, Kerbala 56100, Iraq. ${ }^{4}$ School of Civil Engineering, Iran University of Science and Technology, 1684613114 Narmak, Tehran, Iran. ${ }^{5}$ Kerbala Sewerage Directorate, Kerbala 56001, Iraq. ${ }^{6}$ Green Intelligence Environmental School, Yangtze Normal University, Chongqing 408100, China. ${ }^{7}$ School of Chemical Engineering, Universiti Sains Malaysia, Engineering Campus, Seri Ampangan, 14300 Nibong Tebal, Penang, Malaysia. ${ }^{8}$ Solid Waste Management Cluster, Science and Engineering Research Centre, Universiti Sains Malaysia, Engineering Campus, Seri Ampangan, 14300 Nibong Tebal, Penang, Malaysia. ${ }^{\circledR}$ email: haider.zwain@wrec.voqasim.edu.iq 


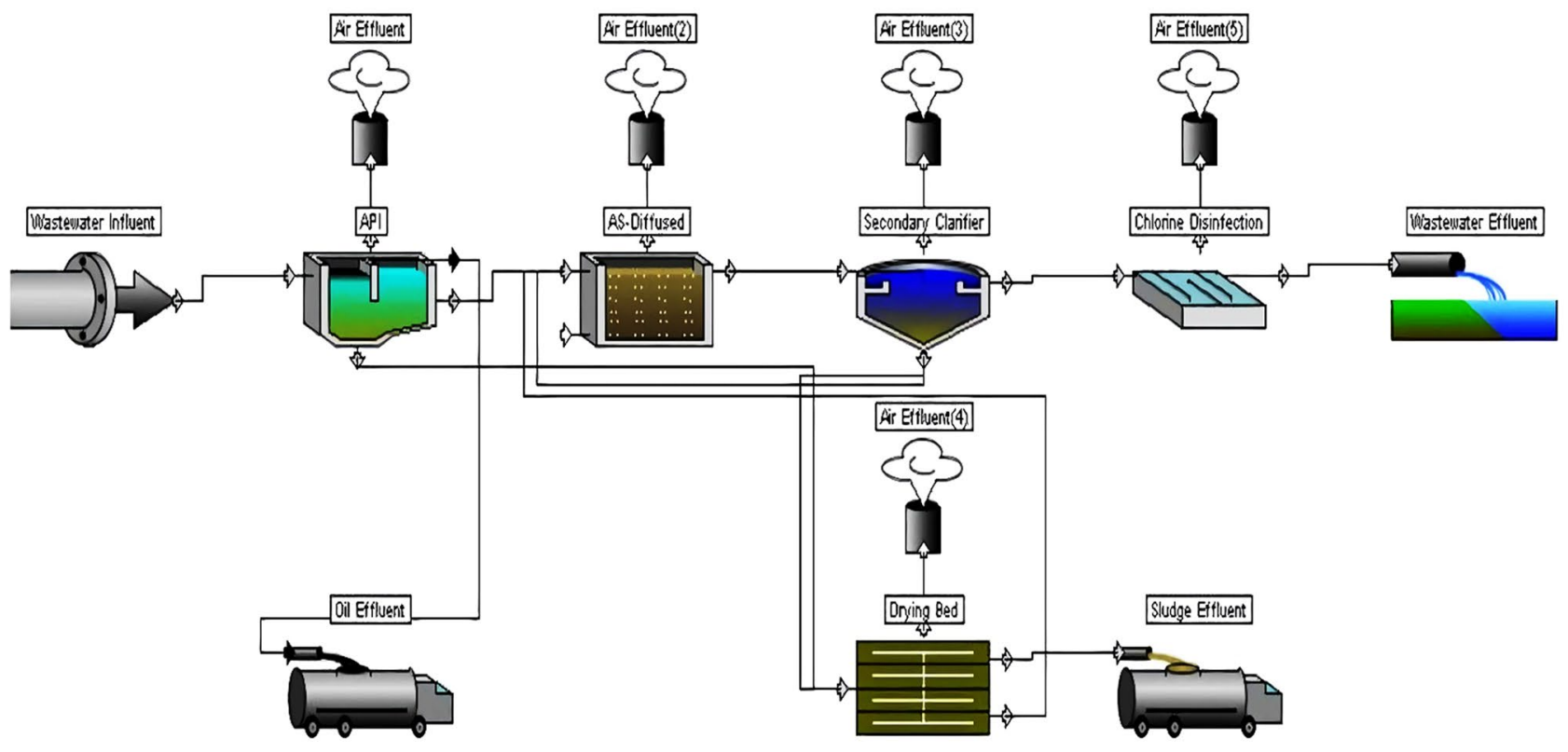

Figure 1. Schematic diagram of EEAS system in MA-STP.

Despite that, there is a high lack of clear legal acts and guidelines regulating $\mathrm{H}_{2} \mathrm{~S}$ emission and dispersion. Hence, a proper control of it is important to reduce nuisances experienced by the exposed populations. The direct way of controlling human exposure to odor is by avoiding the discharge of odor from the origin. Baawain et al. ${ }^{4}$ reported that specific odor exposure can primarily be quantified by the integral results of sources of emission, dispersion route, and characteristics of receptor. Different methods (i.e. models, surveys and chamber monitoring) have been used to study odor nuisance to estimate the degree of odors emission from STP ${ }^{1,2,5,6}$. The management of $\mathrm{H}_{2} \mathrm{~S}$ can be assisted by mathematical models to understand its fate and emission. The mechanisms of pollutants removal in these models are the degradation and volatilization from different processes. Such mechanisms depends on biological reactions and mass transfer in the liquid and gas phases ${ }^{7}$.

Accordingly, TOXCHEM model is an efficient tool for the prediction of volatile organic compounds (VOCs) fate and hazardous air pollutants (HAPs) emission within/from wastewater treatments plants (WWTPs). As an alternative to Water9 software, TOXCHEM was first developed in early 1990s by US Environmental Protection Agency to overcome limitations of Water9. It is based on mass balance of several compounds in WWTPs for each operation unit, taking into account many physical, chemical, and biological processes such as sorption, stripping, volatilization and biodegradation. It is mainly used for VOC air emissions estimates from wastewater collection systems, WWTPs, and disposal facilities. This also include the reduction of air emission by planning, designing and optimization of process projects. In addition, it can also be implemented to predict the loads/ concentrations of contaminants in the water effluent, and residual solids streams ${ }^{8}$.

Karbala state is geologically characterized by gypsum soil and high levels of groundwater, especially in the district where the plant is located. Hence, the groundwater contains very high concentrations of sulfide $\left(\mathrm{SO}_{4}{ }^{2-}\right)$ compounds that infiltrate into the sewer system, leading to increased $\mathrm{SO}_{4}{ }^{2-}$ concentrations in sewage, in addition to several other wastewater sources containing $\mathrm{SO}_{4}{ }^{2-}$. In that sewer systems, sewage are going through oxygen depletion, variable flow rate and velocity, and long retention time that consequently lead to the decomposition of $\mathrm{SO}_{4}{ }^{2-}$ to $\mathrm{H}_{2} \mathrm{~S}$ gas dissolved in wastewater. As a results, Muharram Aisha sewage treatment plant (MA-STP) is receiving high concentrations of $\mathrm{H}_{2} \mathrm{~S}$ that result in the emission of sever odors in the area, which casing problems to the workers and people in the surrounding area. Studies on the modelling of odors exposure associated with $\mathrm{H}_{2} \mathrm{~S}$ from STPs' are very limited. Therefore, the study aims to model the $\mathrm{H}_{2} \mathrm{~S}$ fate at different treatment units of MA-STP and emission from these units to the atmosphere, during summer and winter, using TOXCHEM V4.1 simulations. In addition, sensitivity analysis is conducted to understand the effect of variation in aeration flowrate, $\mathrm{H}_{2} \mathrm{~S}$ loading rate, wastewater $\mathrm{pH}$ level, wastewater temperature and wind speed on the fate and emission of $\mathrm{H}_{2} \mathrm{~S}$.

\section{Materials and methods}

Site location and description. Muhhram Aisha sewage treatment plant (MA-STP) is located in AlHindiya District, at about $20 \mathrm{~km}$ from the center of the Karbala, and nearly $110 \mathrm{~km}$ to the south of Baghdad, the capital of Iraq.

The geographical coordinates of MA-STP are $32^{\circ} 31^{\prime} 41.4516^{\prime \prime} \mathrm{N}$ and $44^{\circ} 13^{\prime} 12.2664^{\prime \prime} \mathrm{E}$ (Latitude: 32.528181 and Longitude: 44.220074). The treatment system used is extended aeration activated sludge (EAAS), as shown in Fig. 1. It is designed to serve 50,000 people with an estimated discharge flow rate of $8000 \mathrm{~m}^{3} /$ day, and the operational conditions are listed in Table 1 . The system consisted of aerated grit chamber with oil-water separator (API) unit, diffused aerated activated sludge unit, secondary clarifier, chlorine disinfection unit, and drying beds unit for sludge management. 


\begin{tabular}{|l|l|}
\hline Parameter & Value \\
\hline Mixed liquor suspended solids (MLSS) $(\mathrm{mg} / \mathrm{L})$ & 3000 \\
\hline Food/microorganism (F/M) ratio $(\mathrm{kg}$ BOD/kg MLVSS day) & 0.09 \\
\hline Solids loading rates (SLR) $\left(\mathrm{kg}\right.$ MLSS $\left./ \mathrm{m}^{2} \mathrm{~h}\right)$ & 2.9 \\
\hline Overflow $\left(\mathrm{m}^{3} / \mathrm{m}^{2}\right.$ day) & 13 \\
\hline Hydraulic retention time (HRT) (h) & 16 \\
\hline Dissolved oxygen $(\mathrm{DO})(\mathrm{mg} / \mathrm{L})$ & 2.5 \\
\hline Solids retention time $(\mathrm{SRT})(\mathrm{day})$ & 25 \\
\hline Return activated sludge $(\mathrm{RAS})(\%)$ & 75 \\
\hline Sludge volume index $(\mathrm{SVI})(\mathrm{mL} / \mathrm{g})$ & 66 \\
\hline Discharge $(\mathrm{Q})\left(\mathrm{m}^{3} / \mathrm{day}\right)$ & 8000 \\
\hline Summer temperature $\left({ }^{\circ} \mathrm{C}\right)$ & 27 \\
\hline Winter temperature $\left({ }^{\circ} \mathrm{C}\right)$ & 12 \\
\hline
\end{tabular}

Table 1. Operational conditions of MASTP-EAAS.

\begin{tabular}{|l|l|l|l|}
\hline Parameter & Influent concentration $(\mathbf{m g} / \mathbf{L})$ & Effluent concentration $(\mathbf{m g} / \mathbf{L})$ & Permissible limits $(\mathbf{m g} / \mathbf{L})$ \\
\hline $\mathrm{pH}$ & 7.2 & 7 & $6-9$ \\
\hline $\mathrm{COD}$ & 450 & 35 & 100 \\
\hline $\mathrm{BOD}$ & 280 & 10 & 40 \\
\hline $\mathrm{TSS}$ & 300 & 20 & 60 \\
\hline $\mathrm{NO}_{3}{ }^{-}$ & 0 & 35 & 50 \\
\hline $\mathrm{NO}_{2}$ & 0 & $\mathrm{ND}$ & - \\
\hline $\mathrm{NH}_{4}{ }^{+}$ & 20 & $\mathrm{ND}$ & 10 \\
\hline $\mathrm{SO}_{4}{ }^{2-}$ & 1050 & 1175 & 400 \\
\hline $\mathrm{H}_{2} \mathrm{~S}^{-}$ & 35 & 1 & 3 \\
\hline $\mathrm{Oil}$ and grease & 40 & 2 & 10 \\
\hline $\mathrm{PO}_{4}{ }^{3-}$ & 15 & 1 & 3 \\
\hline
\end{tabular}

Table 2. Characteristics of influent in MASTP. All parameters in $\mathrm{mg} / \mathrm{L}$ except for $\mathrm{pH}$; ND is not detected $(<1 \mathrm{mg} / \mathrm{L})$.

Sampling and analysis. To assess the performance of the MA-STP, influent and effluent samples were monthly measured from January 2019 to December 2019. Three replicates were analyzed for $\mathrm{pH}, \mathrm{COD}, \mathrm{BOD}_{5}$, TSS, $\mathrm{NO}_{3}{ }^{-}, \mathrm{NO}_{2}, \mathrm{NH}_{4}{ }^{+}, \mathrm{SO}_{4}{ }^{2-}, \mathrm{H}_{2} \mathrm{~S}$, Oil \& grease and $\mathrm{PO}_{4}{ }^{3-}$ as specified by standard procedures for analysis of water and waste water $^{9}$, and only average values were reported. The influent and effluent characteristics is tabulated in Table 2, and the effluents were compared with the Iraqi effluent standard ${ }^{10}$. Throughout the year, the wind speed was ranged from 5 to $25 \mathrm{~km} / \mathrm{h}$, and the direction was mostly north-west $\left(305^{\circ}\right)$. The conversation of soluble $\mathrm{H}_{2} \mathrm{~S}$ in wastewater to gas emitted from STP is calculated based on the following equation derived from the ideal gas law at standard conditions ${ }^{11}$ :

$$
H_{2} \text { S emission }(\mathrm{ppm})=\frac{\left(V \frac{L}{\text { mole of } \mathrm{H}_{2} \mathrm{~S}}\right) \times \mathrm{H}_{2} \mathrm{~S} \text { concentration }(\mathrm{mg} / \mathrm{L})\left(10^{3} \mathrm{~g} / \mathrm{mg}\right)}{\left(34.08 \frac{\mathrm{g}}{\text { mole of } \mathrm{H}_{2} \mathrm{~S}}\right)}
$$

where $\mathrm{V}$ is volume occupied by the gas $(\mathrm{L})=22.414 \mathrm{~L}$ at standard temperature.

Model development. To simulate the $\mathrm{H}_{2} \mathrm{~S}$ fate and emission from various treatment processes in MA-STP during summer and winter, TOXCHEM V4.1 simulation was used. In TOXCHEM V4.1, $\mathrm{H}_{2} \mathrm{~S}$ has similar features like volatile organic compounds (VOC), which can be removed by liquid-gas mass transfer and biodegradation processes. In EAAS system, liquid-gas mass transfer occurs by two mechanisms: first is by volatilization to the atmosphere that is due to striping by diffused bubble aeration and volatilization from open surfaces; second is by sorption process of $\mathrm{H}_{2} \mathrm{~S}$ to the sludge. Fate and emission processes of $\mathrm{H}_{2} \mathrm{~S}$ in the MA-STP can be summarized in the following four methods:

1. Biological sorption of $\mathrm{H}_{2} \mathrm{~S}$ from liquid phase to the sludge formed in the system.

2. Striping by diffused aeration that causes volatilization of $\mathrm{H}_{2} \mathrm{~S}$ to the atmosphere.

3. Volatilization of $\mathrm{H}_{2} \mathrm{~S}$ from open surfaces of treatment units.

4. Biodegradation of $\mathrm{H}_{2} \mathrm{~S}$ by activated sludge process. 
In the MA-STP system, air diffusers have been used to provide aeration at the grit chamber and activated sludge tank. For diffused bubble aeration, the rate of stripping is represented by concentration of pollutants in the wastewater and is written as:

$$
r_{d}=k_{d} \mathrm{C} f_{\text {non }} \mathrm{V}
$$

where $r_{d}$ is diffused aeration stripping rate $(\mathrm{mg} / \mathrm{h}), \mathrm{k}_{\mathrm{d}}$ is diffused aeration stripping constant, $\mathrm{C}$ is volatile compound concentration in the water $\left(\mathrm{mg} / \mathrm{m}^{3}\right), \mathrm{f}_{\text {non }}$ is $\mathrm{pH}$ dependent fraction of non-dissociated compound, and $\mathrm{V}$ is aeration basin volume $\left(\mathrm{m}^{3}\right)$.

It is assumed that the motion of air on the top of basin (i.e. open system) is adequate to volatilize $\mathrm{H}_{2} \mathrm{~S}$, thus the volatilization rate is given by:

$$
r_{v}=k_{v} \mathrm{C} f_{\text {non }} \mathrm{V}
$$

where $r_{v}$ is rate of volatilization $(\mathrm{mg} / \mathrm{h})$, and $\mathrm{k}_{\mathrm{v}}$ is volatilization rate constant $(1 / \mathrm{h})$.

Due to that MA-STP system is based on suspended growth mechanisms, suspended growth biodegradation was used in the model. Subsequently, $\mathrm{H}_{2} \mathrm{~S}$ biodegradation is expressed by Monod reaction as shown in the following equation:

$$
r_{b}=k_{b}\left(\frac{C}{1+\frac{C}{K_{s}}}\right) X V
$$

where $r_{b}$ is the biodegradation rate $(\mathrm{mg} / \mathrm{h}), \mathrm{k}_{\mathrm{b}}$ is the coefficient of first order biodegradation rate $(\mathrm{L} / \mathrm{mg} \mathrm{VSS} / \mathrm{h})$, $\mathrm{X}$ is the biomass concentration $(\mathrm{mg} / \mathrm{L})$, and $\mathrm{K}_{\mathrm{s}}$ is the half saturation constant $(\mathrm{mg} / \mathrm{L})$.

$\mathrm{H}_{2} \mathrm{~S}$ transfers from the liquid phase to the suspended solids and to the residual dead biomass by mean of sorption. Sorption of $\mathrm{H}_{2} \mathrm{~S}$ onto the sludge is described by a linear isotherm in low pollutant concentrations and it is computed by the following equation:

$$
q=K_{p} C
$$

where $\mathrm{q}$ is the pollutant concentration in solid phase $(\mu \mathrm{g} / \mathrm{g})$, and $\mathrm{K}_{\mathrm{p}}$ is the coefficient of sorption partition $(\mathrm{L} / \mathrm{g})$.

Model validation. To evaluate the characteristic of data predicted by TOXCHEM V4.1, all measured and predicted data were compared using the statistical parameters recommended by Chang and Hanna ${ }^{12}$, which include fractional bias (FB), geometric mean bias (MG), normalized mean square error (NMSE), geometric variance (VG), correlation coefficient (R), and fraction of predictions within a factor of two observations (FAC2). Results of measured $\mathrm{H}_{2} \mathrm{~S}$ values discharged with effluent and emitted to atmosphere in 12 months are compared with the predicted $\mathrm{H}_{2} \mathrm{~S}$ values by TOXCHEM V4.1. The statistical parameters used are presented in Eqs. (6)(11):

$$
\begin{gathered}
F B=\frac{\left(\overline{C_{o}}-\overline{C_{p}}\right)}{\left.0.5 \overline{C_{o}}+\overline{C_{p}}\right)} \\
M G=\exp \left(\overline{\ln C_{o}}-\overline{\ln C_{p}}\right) \\
N M S E=\frac{\overline{\left(C_{o}-C_{p}\right)^{2}}}{\overline{C_{o} C_{p}}} \\
V G=\exp \overline{\left(\ln C_{o}-\ln C_{p}\right)^{2}} \\
R=\frac{\left(C_{o}-\overline{C_{o}}\right)\left(C_{p}-\overline{C_{p}}\right)}{\sigma C_{o} \sigma C_{p}} \\
F A C 2=\overline{\left(\frac{C_{p}}{C_{o}}\right)}
\end{gathered}
$$

where $C_{o}$ is the measured $\mathrm{H}_{2} \mathrm{~S}$ value, $C_{p}$ is the predicted $\mathrm{H}_{2} \mathrm{~S}$ value, $\overline{C_{o}}$ is the average over measured data, $\overline{C_{p}}$ is the average over predicted data, and $\sigma$ is the standard deviation over the dataset. The acceptable limits for these statistical parameters are shown in Table 3.

Sensitivity analysis. Among many crucial processes to understand the effect of various operational parameters on the fate and emission of $\mathrm{H}_{2} \mathrm{~S}$ is sensitivity analysis. In this investigation, sensitivity analysis was applied to comprehend the fate and emission of $\mathrm{H}_{2} \mathrm{~S}$ by using the major influencing parameters on the treatment process of extended aeration systems, which include aeration flowrate, $\mathrm{H}_{2} \mathrm{~S}$ loading rate (MLSS concentration in the diffused aerated activated sludge reactor), wastewater $\mathrm{pH}$ level, wastewater temperature and wind speed. Differ- 


\begin{tabular}{|c|c|c|c|c|c|c|}
\hline \multirow[b]{2}{*}{ Parameter } & \multicolumn{2}{|c|}{$\begin{array}{l}\text { Discharged with } \\
\text { effluent }\end{array}$} & \multicolumn{2}{|c|}{ Emitted to atmosphere } & \multirow[b]{2}{*}{ Ideal fit } & \multirow[b]{2}{*}{ Validation limits } \\
\hline & Measured & Predicted & Measured & Predicted & & \\
\hline Average & 0.48 & 0.37 & 4.46 & 5.98 & & \\
\hline Standard deviation & 0.21 & 0.17 & 0.29 & 0.35 & & \\
\hline Fractional bias (FB) & \multicolumn{2}{|l|}{0.25} & \multicolumn{2}{|l|}{-0.29} & 0 & $-0.3 \leq F B \leq 0.3$ \\
\hline Geometric mean bias (MG) & \multicolumn{2}{|l|}{1.28} & \multicolumn{2}{|l|}{0.75} & 1 & $0.7 \leq M G \leq 1.3$ \\
\hline Normalized mean square error (NMSE) & \multicolumn{2}{|l|}{0.08} & \multicolumn{2}{|l|}{0.09} & 0 & $\leq 1.5$ \\
\hline geometric variance $(\mathrm{VG})$ & \multicolumn{2}{|l|}{1.08} & \multicolumn{2}{|l|}{1.09} & 1 & $\leq 4$ \\
\hline Correlation coefficient (R) & \multicolumn{2}{|l|}{0.9} & \multicolumn{2}{|l|}{0.89} & 1 & Close to 1 \\
\hline Factor of two observations (FAC2) (\%) & \multicolumn{2}{|l|}{0.78} & \multicolumn{2}{|l|}{1.34} & 1 & $0.5 \leq F A C 2 \leq 2$ \\
\hline
\end{tabular}

Table 3. Statistical parameters of data validation of $\mathrm{H}_{2} \mathrm{~S}$ emitted to atmosphere and discharged with effluent.

ent aeration flowrate (2500-15,000 $\left.\mathrm{m}^{3} / \mathrm{h}\right), \mathrm{H}_{2} \mathrm{~S}$ loading rate (5-35 $\mathrm{mg} \mathrm{H}_{2} \mathrm{~S} / \mathrm{g}$ MLSS/day), wastewater $\mathrm{pH}$ levels (5-10), wastewater temperatures $\left(10-30^{\circ} \mathrm{C}\right)$, and wind speeds $(5-25 \mathrm{~km} / \mathrm{h})$ were applied.

\section{Results and discussion}

The performance evaluation of MA-STP. Table 2 shows the performance evaluation of the MA-STP Al-Hindiya District, Karbala, Iraq. Removal efficiency of 92, 96, 93, 100, 98, 95 and 93\% were achieved for COD, $\mathrm{BOD}_{5}$, TSS, $\mathrm{NH}_{4}{ }^{+}, \mathrm{H}_{2} \mathrm{~S}$, Oil \& grease and $\mathrm{PO}_{4}{ }^{3-}$, respectively. According to the Iraqi standards ${ }^{10}$, the MA-STP performed very well to remediate all pollutants, except for $\mathrm{SO}_{4}{ }^{2-}$. High influent $\mathrm{SO}_{4}{ }^{2-}$ concentration and oxidation of $\mathrm{H}_{2} \mathrm{~S}$ result in excess presence of $\mathrm{SO}_{4}{ }^{2-}$ concentration in the system ${ }^{13}$, therefor it is higher in effluent than the influent. However, neutral $\mathrm{pH}$ and high degradation of organics indicated a stable biological process. $\mathrm{NH}_{4}^{+}$ and $\mathrm{NO}_{2}$ was not detected in the effluent due to complete nitrification process achieved by the EAAS system ${ }^{8}$. In contrast, about $35 \mathrm{mg} / \mathrm{L}_{\text {of }} \mathrm{NO}_{3}{ }^{-}$was observed in the effluent because the treatment system does not include denitrification process that need to be considered to improve the system performance. Furthermore, high oil \& grease removal attributed to the application of oil-water separator (API) in the aerated grit chamber. Besides, dissolved $\mathrm{H}_{2} \mathrm{~S}$ was detected at trace level in the effluent, because most of it was degraded in the treatment process and the rest was emitted to the atmosphere.

Results validation. TOXCHEM V4.1 model is used to simulate the $\mathrm{H}_{2} \mathrm{~S}$ fate throughout the MA-STP and emission out of it. The influent characteristics and EAAS system operational conditions were the inputs, and $\mathrm{H}_{2} \mathrm{~S}$ fate $(\%$ and $\mathrm{mg} / \mathrm{L})$ and emission values $(\mathrm{ppm})$ were the output of the model. From these applied characteristic and operational variables, model simulations were generated and compared with $\mathrm{H}_{2} \mathrm{~S}$ analysis in the sampling points of emitted $\mathrm{H}_{2} \mathrm{~S}$ at the top of each treatment unit and dissolved $\mathrm{H}_{2} \mathrm{~S}$ with effluent. Table 3 presents statistical data validation of predicted and measured $\mathrm{H}_{2} \mathrm{~S}$ emitted to atmosphere and discharged with effluent. In comparison, all data were validated within the limits, and dataset NMSE, VG, and R were close to the ideal fit.

FB and MG measure mean bias and indicate systematic errors which lead to underestimate or overestimate the measured data. FB of 0.25 (more than zero) and MG of 1.28 (more than one) evidence that TOXCHEM under predicted $\mathrm{H}_{2} \mathrm{~S}$ concentration discharged with effluent, while FB of -0.29 (less than zero) and MG of 0.75 (less than one) indicate that the model over predicted $\mathrm{H}_{2} \mathrm{~S}$ emission to atmosphere. However, both of $\mathrm{FB}$ and MG showed that the error in all data are within acceptable limits and less than 30\%. NMSE and VG showed that data scattering around the true value and they both reflected systematic random errors from unpredictable fluctuations. The results of both of NMSE and VG are very close to ideal fit, indicating that there is no random error for the predicted data over measured.

The coefficient of correlation $(\mathrm{R})$ reflects the linear relationship between modeled and observed data. Both $R$ values, 0.9 for $\mathrm{H}_{2} \mathrm{~S}$ concentration discharged with effluent and 0.89 for $\mathrm{H}_{2} \mathrm{~S}$ emission to atmosphere, indicated a strong correlation between predicted and measured data. The highest $\mathrm{R}$ values is required but not sufficient, therefore FAC2 is important factor for evaluation and validation as it's the most robust measure that is not affected by either low or high outliers. The results of FAC2 revealed that $78 \%(\mathrm{FAC} 2=0.78)$ of $\mathrm{H}_{2} \mathrm{~S}$ concentration discharged with effluent and $75 \%(\mathrm{FAC} 2=1.34) \mathrm{of}_{2} \mathrm{~S}$ emission to atmosphere were within a factor of two of the measured data.

In addition, Fig. 2 shows a scattering comparison of measured and predicted $\mathrm{H}_{2} \mathrm{~S}$ that are emitted to atmosphere and discharged with effluent. Distribution of data and coefficient of determination $\left(\mathrm{R}^{2}\right)$ are adopted to check the goodness of model fit. The results showed that the predicted and measured data were well scattered around the linear line, where measured emission was slightly less than predicted and measured discharged concentration was slightly higher than the predicted, and $\mathrm{R}^{2}$ values showed that data are in a good fit. The TOXCHEM model could sufficiently describe the experimental data of $\mathrm{H}_{2} \mathrm{~S}$ fate and emission. In comparison with other studies on the modeling of $\mathrm{H}_{2} \mathrm{~S}$ using AERMOD ${ }^{7}, \mathrm{CALPUFF}^{14}$, and GOSTELOW ${ }^{15}$, statistical analysis of TOXCHEM V4.1 model are very satisfactory to study $\mathrm{H}_{2} \mathrm{~S}$ due to valid prediction with less limitations and errors.

$\mathrm{H}_{2} \mathrm{~S}$ fate and emission. STP are a major source of gaseous emissions that contain odorants and greenhouse gases. Figure 3 shows the $\mathrm{H}_{2} \mathrm{~S}$ fate (\%) throughout the MA-STP. The EAAS system receives about $280 \mathrm{~kg} / \mathrm{day}$ of 
a)

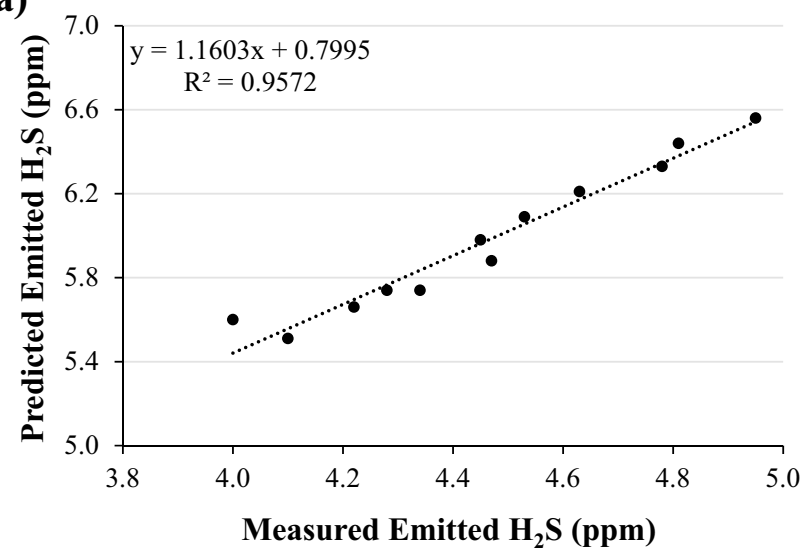

b)

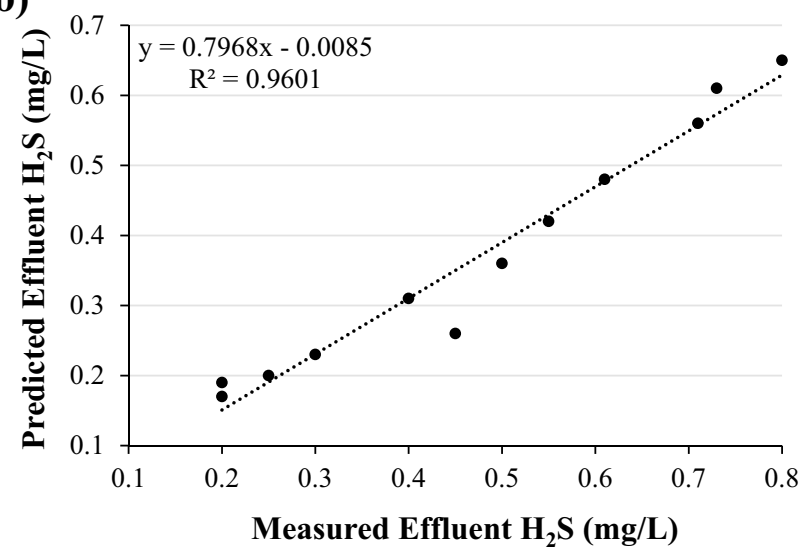

Figure 2. The comparison of measured (x-axis) and predicted ( $\mathrm{y}$-axis) $\mathrm{H}_{2} \mathrm{~S}$ : (a) emitted to atmosphere and (b) discharged with effluent.

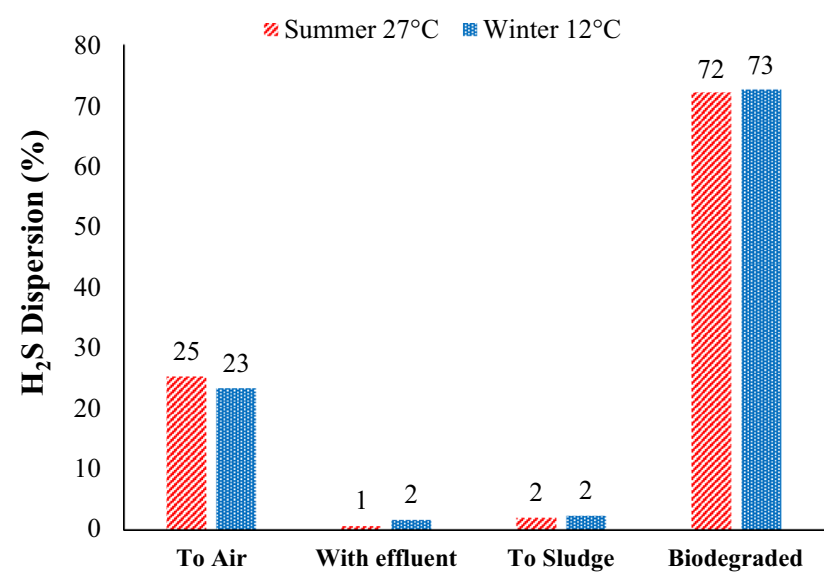

Figure 3. $\mathrm{H}_{2} \mathrm{~S}$ dispersion (\%) throughout the EEAS system in MA-STP during summer and winter.

$\mathrm{H}_{2} \mathrm{~S}$ that is processed throughout the treatment units. During summer $\left(27^{\circ} \mathrm{C}\right)$ and winter $\left(12{ }^{\circ} \mathrm{C}\right)$, about 25 and $23 \%, 1$ and $2 \%, 2$ and $2 \%$, and 72 and $73 \%$ were fated as emitted to air, discharged with effluent, sorbed to sludge, and biodegraded, respectively. The results revealed that the major processes occurring are: (1) degradation, where most of the $\mathrm{H}_{2} \mathrm{~S}$ was oxidized by aerobic process; and (2) emission, where some of the $\mathrm{H}_{2} \mathrm{~S}$ was emitted to the atmosphere by $\mathrm{H}_{2} \mathrm{~S}$ stripping and vitalization from open surfaces. In addition to seasonal variation, sorption of $\mathrm{H}_{2} \mathrm{~S}$ to the dead biomass and discharge of $\mathrm{H}_{2} \mathrm{~S}$ with effluent were slightly observed. Although the key function 


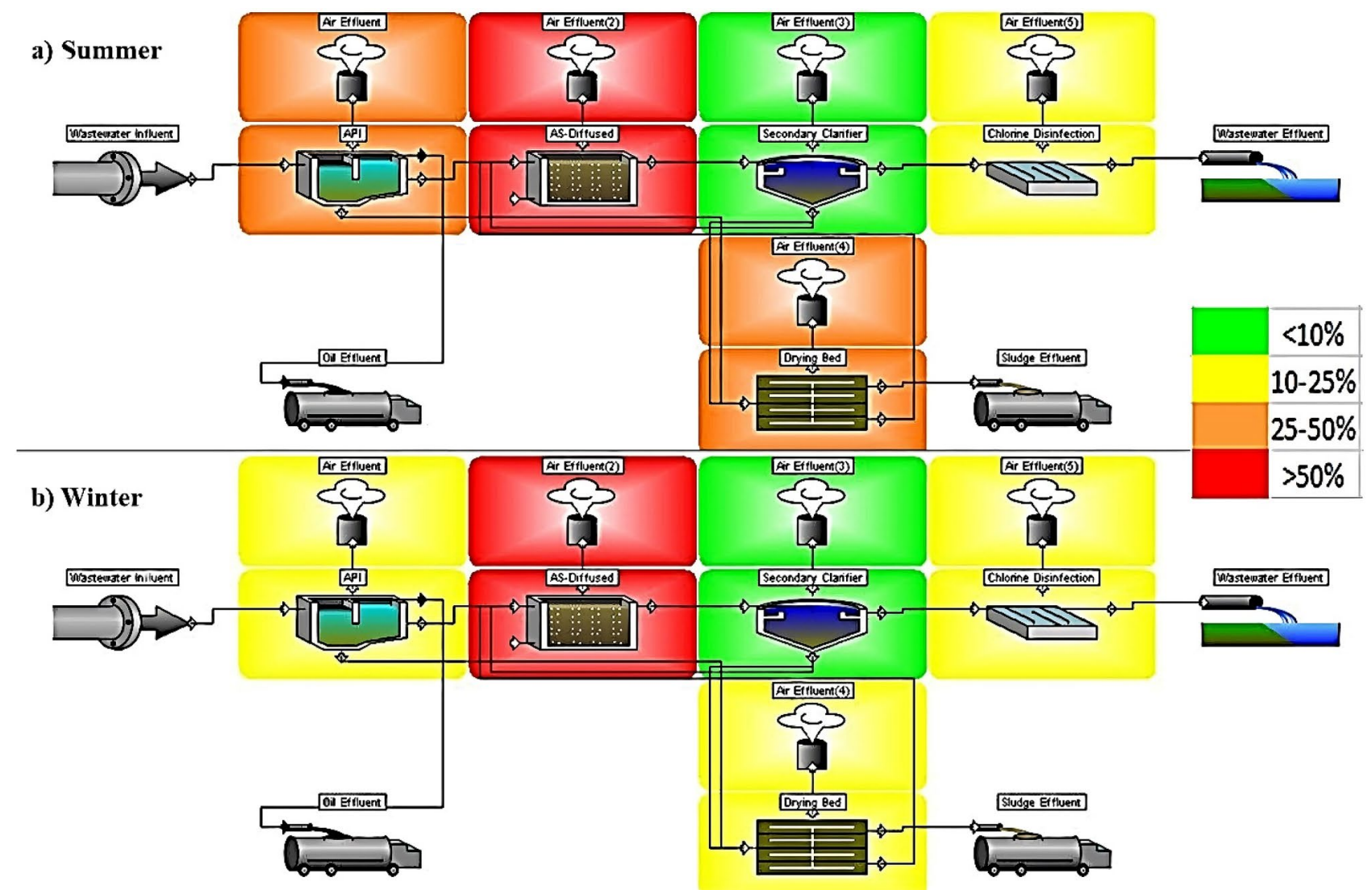

Figure 4. Emission of $\mathrm{H}_{2} \mathrm{~S}$ to atmosphere from each unit (\% of the total emission): (a) summer and (b) winter.

of activated sludge process is to eliminate organic pollutants, the EAAS system has successfully achieved desulfurization of about $74 \%$ of $\mathrm{H}_{2} \mathrm{~S}$ (degradation and sorption).

In an aerobic conditions, natural microorganisms called sulfide oxidizing bacteria (SOB) play a major role in the desulfurization of $\mathrm{H}_{2} \mathrm{~S} . \mathrm{H}_{2} \mathrm{~S}$ is oxidized by chemolithoautotrophic bacteria from the genus Thiobacillus group that has high affinity to sulfide compounds $\left(\mathrm{H}_{2} \mathrm{~S}, \mathrm{HS}^{-} \text {and } \mathrm{S}^{2-}\right)^{16}$. In aqueous solution, $\mathrm{H}_{2} \mathrm{~S}$ presents in forms that are highly depending on $\mathrm{pH}$ level. As the sewage $\mathrm{pH}$ is about 7 at STP, $\mathrm{H}_{2} \mathrm{~S}$ is primarily dissociates to form bisulfide $\left(\mathrm{HS}^{-}\right.$) (Eq. (12)). Sulfide $\left(\mathrm{S}^{2-}\right)$ is another form of $\mathrm{H}_{2} \mathrm{~S}$ (Eq. (13)) that is generally neglected because of its insignificant presence except at very high $\mathrm{pH}$, and $\mathrm{H}_{2} \mathrm{~S}$ form may be predominant below $\mathrm{pH} 5^{13}$.

$$
\begin{gathered}
\mathrm{H}_{2} \mathrm{~S}_{\text {(aqueous) }} \rightarrow \mathrm{HS}^{-}+\mathrm{H}^{+}(\mathrm{pKa}=7.05,5<\mathrm{pH} \leq 10) \\
\mathrm{HS}^{-} \rightarrow \mathrm{S}^{2-}+\mathrm{H}^{+}(\mathrm{pKa}=12.9, \mathrm{pH} \geq 11)
\end{gathered}
$$

In STP where aeration is provided, $\mathrm{HS}^{-}$is biologically oxidized to firstly elemental sulfur $\left(\mathrm{S}^{0}\right)$ and subsequently to sulfate $\left(\mathrm{SO}_{4}{ }^{2-}\right)$, as shown in the following reactions ${ }^{17}$ :

$$
\begin{gathered}
\mathrm{HS}^{-}+0.5 \mathrm{O}_{2} \rightarrow \mathrm{S}^{0}+\mathrm{OH}^{-} \\
\mathrm{S}^{0}+\mathrm{OH}^{-}+1.5 \mathrm{O}_{2} \rightarrow \mathrm{SO}_{4}^{2-}+\mathrm{H}^{+}
\end{gathered}
$$

Complete oxidation of $\mathrm{HS}^{-}$to $\mathrm{SO}_{4}{ }^{2-}$ requires the consumption of two oxygen molecules, but this reaction is reversible if limited amount of oxygen is supplied and elemental $S^{0}$ might accumulate ${ }^{13}$. However, elemental $S^{0}$ is end-product of oxidation process that is necessary for the growth of microorganisms and directly consumed for the synthesis of cellular protein needed for new cells production ${ }^{18}$. Excess amounts of elemental $S^{0}$ and $\mathrm{SO}_{4}{ }^{2-}$ are sorbed to the biomass and/or released with the effluent.

Volatilization describes the process whereby an odorant $\left(\mathrm{H}_{2} \mathrm{~S}\right)$ is transferred from an area source such as the surface of diffused aerated activated sludge reactor to the atmosphere ${ }^{15}$. Figure 3 displays that about $70 \mathrm{~kg} /$ day $(23 \%)$ of total $\mathrm{H}_{2} \mathrm{~S}$ was volatized from the MA-STP to atmosphere, and Fig. 4 shows the emission distribution of $\mathrm{H}_{2} \mathrm{~S}$ from each unit (\% of the total emission). The results revealed that summer has emitted higher $\mathrm{H}_{2} \mathrm{~S}$ compared to winter, in which most of it was from diffused aerated activated sludge reactor $(>50 \%)$, followed by aerated grit chamber (API) (25-50\%) and sludge drying beds (25-50\%). The mechanism of $\mathrm{H}_{2} \mathrm{~S}$ emission is volatilization by air stripping and open surfaces. The $\mathrm{H}_{2} \mathrm{~S}$ emission is a physicochemical process that contains 


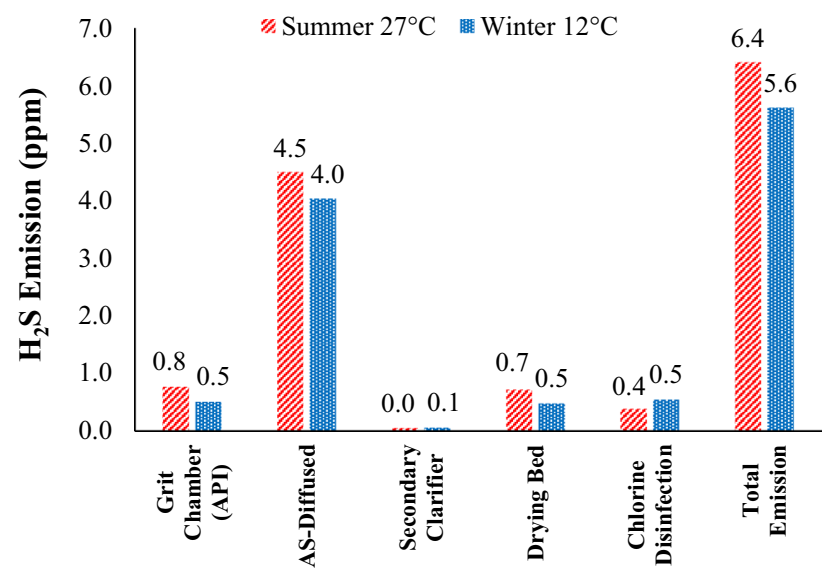

Figure 5. Emission of $\mathrm{H}_{2} \mathrm{~S}$ to atmosphere from each unit (ppm) during summer and winter.

liquid and gas phases. Only $\mathrm{H}_{2} \mathrm{~S}$ (aqueous) can transfer across the sewage-air interface, allowing it to be emitted as gas from STP ${ }^{19}$, as shown in Eq. (16).

$$
\mathrm{H}_{2} \mathrm{~S}_{\text {(aqueous) }} \rightarrow \mathrm{H}_{2} \mathrm{~S}_{\text {(gas) }}\left(\mathrm{K}_{\mathrm{C}} \approx 468 \text { atm/mole fraction }\right)
$$

A STP brings huge quantities of sewage into contact with air that boost the stripping of odorants, which can be significant odor source. Due to aeration process, biological oxidation tends to decrease liquid-phase odorant concentrations. However, recycling of activated sludge is a notable way for odor control due to the recycling of biomass containing sulfur compounds from secondary clarifiers to the aerobic activated sludge reactors. This fosters the consumption of odor compounds before they volatilize from the liquid phase to the atmosphere ${ }^{16}$. Furthermore, the available surface area for gas transfer is believed to affect the emission of $\mathrm{H}_{2} \mathrm{~S}$ from open surfaces to the atmosphere. This was also proved by Parsons et al. ${ }^{20}$ whom found that the greater open surface area of the source the greater $\mathrm{H}_{2} \mathrm{~S}$ concentration emitted to atmosphere.

Figure 5 shows the concentration of $\mathrm{H}_{2} \mathrm{~S}(\mathrm{ppm})$ emitted to atmosphere from each unit. At summer and winter, the total emission were 6.403 and $5.614 \mathrm{ppm}$, from diffused aerated activated sludge reactor were 4.492 and $4.035 \mathrm{ppm}$, from aerated grit chamber (API) were 0.768 and $0.507 \mathrm{ppm}$, from sludge drying beds were 0.718 and $0.475 \mathrm{ppm}$, from secondary clarifier 0.379 and $0.541 \mathrm{ppm}$, and from chlorine disinfection were 0.046 and $0.056 \mathrm{ppm}$, respectively. The results indicated that $\mathrm{H}_{2} \mathrm{~S}$ emission from all units was within the human odor threshold $(0.0005-1.5 \mathrm{ppm})^{3}$, except for diffused aerated activated sludge reactor that was much higher. Long human's exposure $(8 \mathrm{~h}$ ) to concentrations higher than $5 \mathrm{ppm}$ (total emission in this study) may cause headache, nausea and tearing of eyes. Therefore, MA-STP workers are exposed to health rick due to their exposure to high concentrations of $\mathrm{H}_{2} \mathrm{~S}$ that required odor control system (especially at diffused aerated activated sludge reactor), the modification of operational process, or/and shorter working schedule.

Sensitivity analysis. $\mathrm{H}_{2} \mathrm{~S}$ fate and emission within/from EAAS system are affected by operational parameters such as aeration flowrate, $\mathrm{H}_{2} \mathrm{~S}$ loading rate, wastewater $\mathrm{pH}$ level, wastewater temperature and wind speed. Figure 6a demonstrates the effect of aeration flowrate $\left(2500-15,000 \mathrm{~m}^{3} / \mathrm{h}\right)$ on the fate of $\mathrm{H}_{2} \mathrm{~S} . \mathrm{H}_{2} \mathrm{~S}$ sorption to sludge and discharge with effluent was not affected by change in aeration flowrate, compared to biodegradation and volatilization processes. Interestingly, increase in aeration flowrate from 2500 to $15,000 \mathrm{~m}^{3} / \mathrm{h}$ has increased the emission of $\mathrm{H}_{2} \mathrm{~S}$ to atmosphere from 18 to $45 \%$, and decreased biodegradation process from 80 to $52 \%$. The authors cannot negate that there are several evidences on aeration causes odorants stripping by air bubbles, for instance, Baawain et al. ${ }^{2}$ reported that emissions of $\mathrm{H}_{2} \mathrm{~S}$ was intensified by air bubbles during the aeration process. In another study by Tzvi and $\mathrm{Paz}^{13}$, they stated that $15-30 \% \mathrm{of}_{2} \mathrm{~S}$ was evaporated within the air bubbles introduced to the system and released to the atmosphere, which was much higher than operating the system in absence of bubbles streams. In aeration reactor, $\mathrm{H}_{2} \mathrm{~S}$ emission to the atmosphere by stripping and volatilization from open surfaces may occur first, then followed by oxidation of $\mathrm{H}_{2} \mathrm{~S}$ by aerobic microorganisms. Hence, monitoring $\mathrm{H}_{2} \mathrm{~S}$ emission from aeration stream is not only necessary to evaluate $\mathrm{H}_{2} \mathrm{~S}$ fate but also for safety aspects. Therefore, operating the EAAS system at lowest aeration flowrate will reduce the emission of odorants and increase biodegradation treatment.

Figure $6 \mathrm{~b}$ describes the effect of $\mathrm{H}_{2} \mathrm{~S}$ loading rate (MLSS concentration in the diffused aerated activated sludge reactor) on the fate of $\mathrm{H}_{2} \mathrm{~S}$. It is notable that decrease in the $\mathrm{H}_{2} \mathrm{~S}$ loading rate (increase in MLSS concentration) from 35 to $5 \mathrm{mg} \mathrm{H}_{2} \mathrm{~S} / \mathrm{g}$ MLSS/day has enhanced biodegradation process from 45 to $82 \%$, improved sorption process from 1 to $4 \%$, decreased emission to atmosphere from 50 to $13 \%$, and reduced discharge with effluent from 4 to $1 \%$. There is an inverse correlation between $\mathrm{H}_{2} \mathrm{~S}$ loading rate and removal efficiency ${ }^{21}$, in which an increase in $\mathrm{H}_{2} \mathrm{~S}$ loading rate will first decrease the biomass activity resulting in lower biodegradation process leading to decreased $\mathrm{H}_{2} \mathrm{~S}$ removal efficiency, and second increase aqueous $\mathrm{H}_{2} \mathrm{~S}$ concentration available for $\mathrm{H}_{2} \mathrm{~S}$ emission to atmosphere and/or discharged with effluent. 

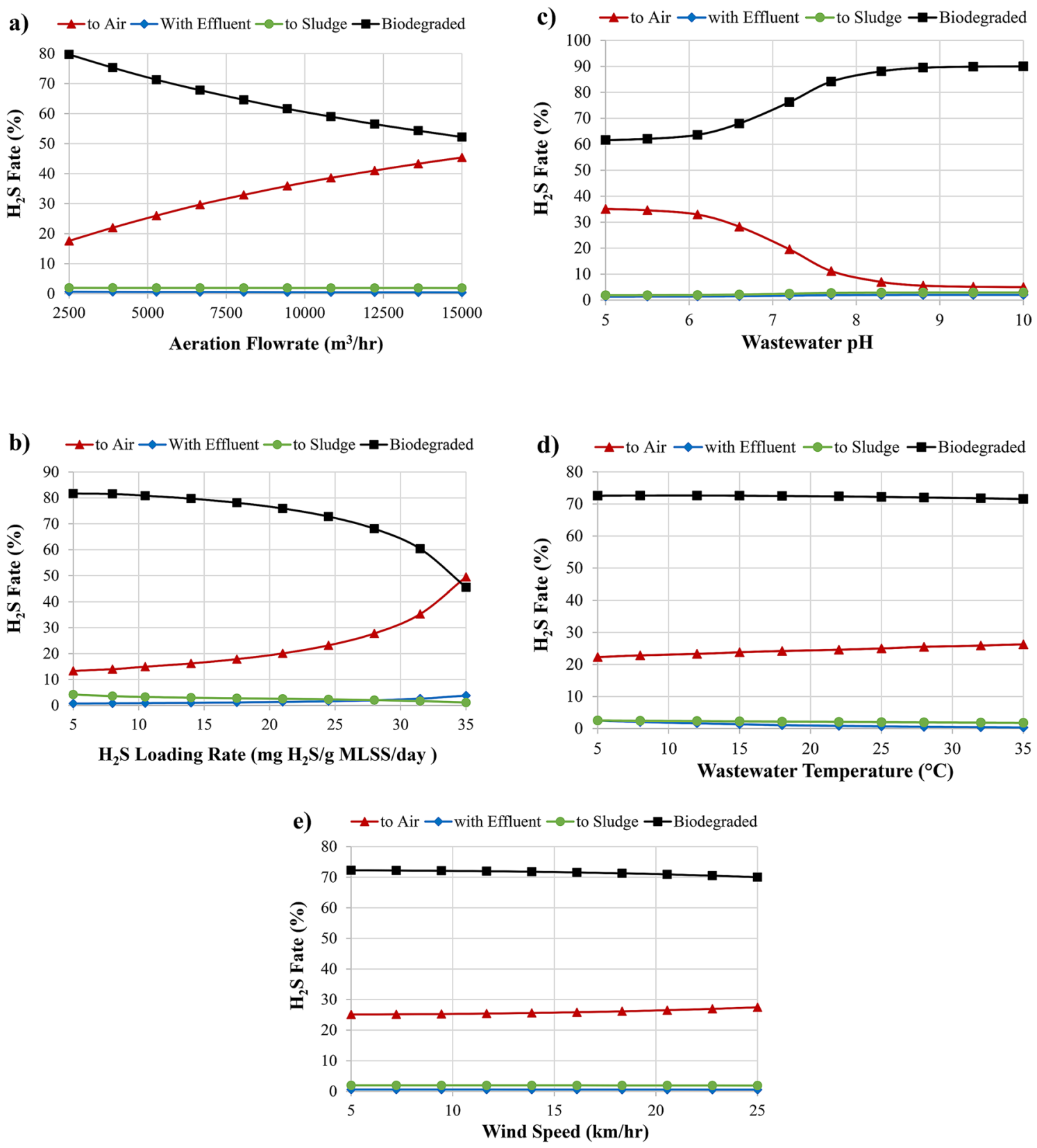

Figure 6. Sensitivity analysis of different $\mathrm{H}_{2} \mathrm{~S}$ dispersion: (a) aeration flowrate, (b) MLSS concentration, (c) wastewater $\mathrm{pH}$ level, (d) wastewater temperature, and (e) wind speed.

Figure $6 \mathrm{c}$ displays the effect of wastewater $\mathrm{pH}$ level on the fate of $\mathrm{H}_{2} \mathrm{~S}$, in which it effects first the dissociation of $\mathrm{H}_{2} \mathrm{~S}$ in aqueous solution, and second the mechanism of $\mathrm{H}_{2} \mathrm{~S}$ removal. The results vouch that increase in $\mathrm{pH}$ between 5 and 10 decreased the emission of $\mathrm{H}_{2} \mathrm{~S}$ to atmosphere from 35 to $5 \%$, making it more dissolved in sewage and increased biodegradation process from 62 to $90 \%$, whereas sorption to sludge and discharge with effluent were not much effected. As $\mathrm{pH}$ increases, the fraction of available $\mathrm{H}_{2} \mathrm{~S}$ decreases due to its dissociation into $\mathrm{HS}^{-}$(Eqs. (12), (13)). Higher $\mathrm{pH}$ solution led to less $\mathrm{H}_{2} \mathrm{~S}$ available for transferring from STP treatment units into the atmosphere, whereas $\mathrm{H}_{2} \mathrm{~S}$ stripping is favored under acidic conditions ${ }^{17}$. Chaiprapat et al. ${ }^{22}$ observed that as $\mathrm{pH}$ of the wastewater decreased, the efficiency of $\mathrm{H}_{2} \mathrm{~S}$ removal of the system slightly decreased due to lowered solubility of $\mathrm{H}_{2} \mathrm{~S}$, which lead to higher ionic strength of wastewater. Low solubility makes $\mathrm{H}_{2} \mathrm{~S}_{\text {and }} \mathrm{O}_{2}$ in gas form become deficient for SOB to execute biochemical reactions in the liquid form.

Moreover, the oxidation of sulfide compounds produces $\mathrm{H}^{+}$(Eq. (17)), leading to drop in the $\mathrm{pH}$ in the aerobic unit of STP. Low $\mathrm{pH}$ level may inhibit biodegradation process because under acidic environment, $\mathrm{H}_{2} \mathrm{~S}$ is unionized and has neutral molecule that is very toxic to microorganism in the system as it can permeate through the cell membrane better than $\mathrm{HS}^{-}$and $\mathrm{S}^{2-1}$. However, continuous wastewater feeding in STP provides recirculation and alkalinity buffering to maintain $\mathrm{pH}$ and hinder acidity. This indicate that using aeration for biological oxidation wouldn't results in external release of $\mathrm{H}_{2} \mathrm{~S}$, and decrease the risk of $\mathrm{H}_{2} \mathrm{~S}$ stripping. 


$$
\mathrm{HS}^{-}+2 \mathrm{O}_{2} \rightarrow \mathrm{SO}_{4}^{2-}+\mathrm{H}^{+}
$$

Temperature is another key factor influencing the physicochemical properties of gases, influencing the Henry gas law and kinetics of biological processes. Figure $6 \mathrm{~d}$ presents the effect of wastewater temperature ranges from 5 to $35^{\circ} \mathrm{C}$ on the fate of $\mathrm{H}_{2} \mathrm{~S}$. It was observed that temperature mainly effected the mass transfer of $\mathrm{H}_{2} \mathrm{~S}$, either dissolved in wastewater or volatized to atmosphere. Increase in temperature from 5 to 35 has increased the emission of $\mathrm{H}_{2} \mathrm{~S}$ from 22 to $27 \%$ and decreased its content in wastewater from 3 to $0 \%$, while effects on degradation and sorption processes were limited. The findings evince that aqueous $\mathrm{H}_{2} \mathrm{~S}$ condensed at a lower temperature and emitted to atmosphere at high temperature. Similarly, Baawain et al. ${ }^{2}$ confirmed that high temperature has increased $\mathrm{H}_{2} \mathrm{~S}$ emissions from ponds sewage treatment system. Other studies also reported that aqueous solution temperature highly effected the mass transfer rate of $\mathrm{H}_{2} \mathrm{~S}$, in which the overall mass transfer from liquid phase to gas phase increases with temperature ${ }^{6}$.

Figure 6e display the effect of wind speed (friction velocity) on the emission of $\mathrm{H}_{2} \mathrm{~S}$ from STP to the atmosphere. It was seen that increase in wind speed from 5 to $35 \mathrm{~km} / \mathrm{h}$ has slightly increased the volatilization of $\mathrm{H}_{2} \mathrm{~S}$ from 25 to $27 \%$ and decreased degradation process from 72 to $70 \%$, whereas sorption and dissolution of gas in wastewater processes were not affected. However, this can show that wind speed has limited effect on the gas emission but of course will highly influence the dispersion of odors away from its generation source. Similarly, slight higher emission rate of $\mathrm{H}_{2} \mathrm{~S}$ was observed with higher wind speed ${ }^{2}$. Wind speed is usually correlated with mass transfer and emission, where it is evident on wind speeds over $4 \mathrm{~m} / \mathrm{s}$, and nearly undetectable below this speed $^{5}$. However, the wind speed reported to be associated with $\mathrm{H}_{2} \mathrm{~S}$ concentration more than the emission rate, in which higher wind speed dilutes the concentration of $\mathrm{H}_{2} \mathrm{~S}$ and disperses it for long distance ${ }^{6}$. In this regards, Santos et al. ${ }^{15}$ reported that wind speed did not have a significant effect on overall mass transfer of $\mathrm{H}_{2} \mathrm{~S}$, suggesting that volatilization will depend more on turbulence of liquid phase than wind speed.

\section{Conclusion}

TOXCHEM V4.1 simulation showed that EAAS system worked as biological treatment method for the removal of $\mathrm{H}_{2} \mathrm{~S}$. The main processes occurring in the EAAS system are (1) $\mathrm{H}_{2} \mathrm{~S}$ compounds (HS ${ }^{-}$) formation, (2) $\mathrm{H}_{2} \mathrm{~S}$ biological degradation, (3) $\mathrm{H}_{2} \mathrm{~S}$ volatilization, (4) $\mathrm{H}_{2} \mathrm{~S}$ stripping, (5) $\mathrm{H}_{2} \mathrm{~S}$ compounds sorption, and (6) discharged $\mathrm{H}_{2} \mathrm{~S}$ with effluents. The date predicted by TOXCHEM V4.1 simulation were validated and close to ideal fit. The main $\mathrm{H}_{2} \mathrm{~S}$ processes observed were degradation by about $73 \%$ and stripping by about $23 \%$. Total $\mathrm{H}_{2} \mathrm{~S}$ emission from the MA-STP, especially from diffused aerated activated sludge reactor, may put the workers and surrounding population at a health risk. Operating the EAAS system at low aeration flowrate, high MLSS concentration, and slightly high $\mathrm{pH}$ are recommended to limit the emission of $\mathrm{H}_{2} \mathrm{~S}$ to the atmosphere. Thus, TOXCHEM V4.1 model can potentially be utilized for other plants/projects to predict $\mathrm{H}_{2} \mathrm{~S}$ fate and dispersion, and analysis of its results can be used as a beneficial output for decision makers.

Received: 10 October 2020; Accepted: 8 December 2020

Published online: 17 December 2020

\section{References}

1. Sun, S., Jia, T., Chen, K., Peng, Y. \& Zhang, L. Simultaneous removal of hydrogen sulfide and volatile organic sulfur compounds in off-gas mixture from a wastewater treatment plant using a two-stage bio-trickling filter system. Front. Environ. Sci. Eng. 13, 60 (2019).

2. Baawain, M., Al-Mamun, A., Omidvarborna, H. \& Al-Sulaimi, I. N. Measurement, control, and modeling of $\mathrm{H}_{2} \mathrm{~S}$ emissions from a sewage treatment plant. Int. J. Environ. Sci. Technol. 16, 2721-2732 (2018).

3. Occupational Health and Safety Administration (OSHA). Hydrogen Sulfide (US Department of Labors, Occupational Health and Safety Administration, Boise, 2018).

4. Baawain, M., Al-Mamun, A., Omidvarborna, H. \& Al-Jabri, A. Assessment of hydrogen sulfide emission from a sewage treatment plant using AERMOD. Environ. Monit. Assess. 189, 263 (2017).

5. Moreno-Silva, C. et al. Hydrogen sulphide emissions and dispersion modelling from a wastewater reservoir using flux chamber measurements and AERMOD" simulations. Atmos. Environ. 224, 117263 (2020).

6. Carrera, L., Springer, F., Lipeme-Kouyi, G. \& Buffiere, P. A review of sulfide emissions in sewer networks: Overall approach and systemic modelling. Water Sci. Technol. 73, 1231-1242 (2016).

7. Augusto, M. R., Campos, B., Carvalho, V. S. B. \& Calheiros, H. C. Modeling of $\mathrm{H}_{2} \mathrm{~S}$ dispersion in Brazil with Aermod: Case study of water resource recovery facility in south of Brazil. Rev. Bras. Meteorol. 34, 497-504 (2019).

8. Zwain, H. M., Vakili, M., Faris, A. M. \& Dahlan, I. Modeling the fate of phenol in moving bed biofilm reactor sewage treatment plant. In Proc. AICCE' 19. AICCE 2019. Lecture Notes in Civil Engineering (ed. Mohamed-Nazri, F.) (Springer, Cham, 2019).

9. American Public Health Association (APHA). Standard Methods for the Examination of Water and Wastewater (American Public Health Association, American Water Works Association and Water Environment Federation, New York, 2017).

10. Al-Iraqiya, A.-W. Iraqi Regulation Number 3: National Limits for the Use of Secondary Treated Effluents in Agricultural Irrigation 4223-4231 (Ministry of Justice of Iraq, Baghdad, 2012).

11. Burton, F. L. et al. Wastewater Engineering: Treatment and Resource Recovery (McGraw-Hill Education, New York, 2013).

12. Chang, J. C. \& Hanna, S. R. Air quality model performance evaluation. Meteorol. Atmos. Phys. 87, 167-196 (2004).

13. Tzvi, Y. \& Paz, Y. Highly efficient method for oxidation of dissolved hydrogen sulfide in water, utilizing a combination of UVC light and dissolved oxygen. J. Photochem. Photobiol. A 372, 63-70 (2019).

14. Gulia, S., Kumar, A. \& Khare, M. Performance evaluation of CALPUFF and AERMOD dispersion models for air quality assessment of an industrial complex. J. Sci. Ind. Res. 74, 302-307 (2015).

15. Santos, J. M. et al. An experimental determination of the $\mathrm{H}_{2} \mathrm{~S}$ overall mass transfer coefficient from quiescent surfaces at wastewater treatment plants. Atmos. Environ. 60, 18-24 (2012).

16. Barbusiński, K. \& Kalemba, K. Use of biological methods for removal of $\mathrm{H}_{2} \mathrm{~S}$ from biogas in wastewater treatment plants-A review. Archit. Civ. Eng. Environ. 9, 103-112 (2016).

17. Quijano, G., Figueroa-González, I. \& Buitrón, G. Fully aerobic two-step desulfurization process for purification of highly $\mathrm{H}_{2} \mathrm{~S}-\mathrm{laden}_{\mathrm{a}}$ biogas. J. Chem. Technol. Biotechnol. 93, 3553-3561 (2018). 
18. Zhang, L. et al. Chemical and biological technologies for hydrogen sulfide emission control in sewer systems: A review. Water Res. 42, 1-12 (2008).

19. Long, Y., Fang, Y., Shen, D., Feng, H. \& Chen, T. Hydrogen sulfide (H(2)S) emission control by aerobic sulfate reduction in landfill. Sci. Rep. 6, 38103-38103 (2016).

20. Parsons, S. A., Smith, N., Gostelow, P. \& Wishart, J. Hydrogen sulphide dispersion modelling-Urban and rural case studies. Water Sci. Technol. 41, 117-126 (2000).

21. Moussavi, G., Naddafi, K., Mesdaghinia, A. \& Deshusses, M. A. The removal of $\mathrm{H}_{2} \mathrm{~S}$ from process air by diffusion into activated sludge. Environ. Technol. 28, 987-993 (2007).

22. Chaiprapat, S., Mardthing, R., Kantachote, D. \& Karnchanawong, S. Removal of hydrogen sulfide by complete aerobic oxidation in acidic biofiltration. Process Biochem. 46, 344-352 (2011).

\section{Acknowledgements}

Authors around the world are writing their work under many unfortunate situations. On the 2nd of August 2020, I (H.M.Z.) was diagnosed with COVID-19 positive. A feeling of pain, weakness, fair, and uncertainty; I found in completing writing this paper an inspiration to continue living, lift up my self-helpless, and looking forward a full recovery. In this occasion, I would like to thank all researchers around the world who are hardly working to find solutions for this pandemic catastrophe. A special thanks to all physician, including my wife, and medical staff for their sacrifice. I am grateful for my wife and parents for looking after me and not making me feel neglected. Furthermore, the support of Department of Civil and Architectural Engineering, College of Engineering, Sultan Qaboos University is highly appreciated.

\section{Author contributions}

B.K.N. and A.H.F. conceived the study. H.M.Z. conceptualized the methodology, analyzed the data, and wrote the first and successive drafts of the manuscript. M.V. and I.D. contributed to the writing of the manuscript and to the interpretation of results.

\section{Competing interests}

The authors declare no competing interests.

\section{Additional information}

Correspondence and requests for materials should be addressed to H.M.Z.

Reprints and permissions information is available at www.nature.com/reprints.

Publisher's note Springer Nature remains neutral with regard to jurisdictional claims in published maps and institutional affiliations.

(c) (i) Open Access This article is licensed under a Creative Commons Attribution 4.0 International License, which permits use, sharing, adaptation, distribution and reproduction in any medium or format, as long as you give appropriate credit to the original author(s) and the source, provide a link to the Creative Commons licence, and indicate if changes were made. The images or other third party material in this article are included in the article's Creative Commons licence, unless indicated otherwise in a credit line to the material. If material is not included in the article's Creative Commons licence and your intended use is not permitted by statutory regulation or exceeds the permitted use, you will need to obtain permission directly from the copyright holder. To view a copy of this licence, visit http://creativecommons.org/licenses/by/4.0/.

(C) The Author(s) 2020 